\title{
The Tudeh Party of Iran and the peasant question, 1941-53
}

\author{
Siavush Randjbar-Daemi
}

\begin{tabular}{|l|l|}
\hline Date of deposit & 13072020 \\
\hline Document version & Author's accepted manuscript \\
\hline Access rights & $\begin{array}{l}\text { Copyright C 2020 Informa UK Limited, trading as Taylor \& } \\
\text { Francis Group. This work has been made available online in } \\
\text { accordance with publisher policies or with permission. Permission } \\
\text { for further reuse of this content should be sought from the } \\
\text { publisher or the rights holder. This is the author created accepted } \\
\text { manuscript following peer review and may differ slightly from the } \\
\text { final published version. }\end{array}$ \\
\hline $\begin{array}{l}\text { Citation for } \\
\text { published version }\end{array}$ & $\begin{array}{l}\text { Randjbar-Daemi, S 2020, 'The Tudeh Party of Iran and the } \\
\text { peasant question, 1941-53', Middle Eastern Studies, vol. Latest } \\
\text { articles. }\end{array}$ \\
\hline $\begin{array}{l}\text { Link to published } \\
\text { version }\end{array}$ & \begin{tabular}{l} 
https://doi.org/10.1080/00263206.2020.1781627 \\
\hline
\end{tabular}
\end{tabular}

Full metadata for this item is available in St Andrews Research

Repository at: https://research-repository.st-andrews.ac.uk/

\begin{tabular}{ll|l|} 
University of & FOUNDED \\
St Andrews & 1413
\end{tabular}




\title{
The Tudeh Party of Iran and the Peasant Question, 1941-1953.
}

\begin{abstract}
This article will examine the Tudeh Party of Iran's (TPI) attitude and agency towards the peasant question between its foundation in 1941 and the end of the party's ability to operate in the domestic political scene in 1953. Based on a close reading of party printed material and other relevant primary sources from those dozen years, the study will analyse the TPI's attempt to formulate a coherent and practicable stance on the pressing issue of the amelioration of the peasant condition during the early stages of its formation and develop a lasting presence, with varying degrees of success, within the large peasant contingent of the Iranian population of the time until the August 1953 coup d'état which brought an end to the activities of the party's front organisations, including the body devoted to the peasant question.

Besides focusing on the formations through which the Tudeh sought to engage directly with rural communities and formulate a platform based on their grievances and requests, this article will also compare the Tudeh's agency within this segment of the Iranian population with its efforts across other strata of the Iranian society at the time as well as the party's reactions to peasant-oriented initiatives carried out by both local and national administrations during this period.
\end{abstract}

Keywords: Tudeh Party of Iran, Peasant Mobilisation, Agrarian Relations, Communism in Iran, Muhammad Musaddiq. 
As noted by Fakhreddin Azimi, Iran entered the Twentieth century bearing 'few apparent signs of having emerged from the Middle Ages', with a national population of approximately ten million, the majority of whom were of rural or nomadic residence. ${ }^{1}$ As much as 75 per cent of the Iranian population, according to some estimates, continued to reside outside urban centres until the mid-1960s, often in a state of severe destitution. During the latter part of the nineteenth century, the growing financial indigence of the Qajar court was conducive to state- and crownowned arable land being assigned to unscrupulous and profiteering large and often absentee landowners, who in turn engaged in exploitative means of control over the peasants who were working the land.

Since the formation of the initial social-democratic movements at the turn of the twentieth century, the modern Iranian Left has retained an active interest in the plight of rural dwellers. After producing largely rhetorical support during the decades between the outbreak of the Constitutional Revolution in 1906 and the end of Riza Shah's rule in 1941, the lively and pluralistic setting which followed the end of the reign of the first Pahlavi monarch enabled the newly created Tudeh Party of Iran to actively seek to mobilise the population of rural areas across the country and follow up its attempts at organising industrial workers through the creation of a Peasants' Union. Throughout its active, direct presence on the domestic political scene between 1941-53, the Tudeh sought to develop a power-base for itself within the peasant strata of society, and included lengthy segments on the most pressing issue of land reform in the various programmatic resolutions it produced during conferences and two congresses held during those dozen years. From 1951 onwards, a front organisation linked to the party produced the country's first periodical entirely devoted to peasant matters.

Nearly a decade after the Tudeh's expulsion from the political scene as a consequence of the August 1953 coup d'état which ousted prime minister Mohammad Musaddiq, the Pahlavi state finally implemented the first, systematic nationwide reform of rural land ownership in 
Iran's modern history, echoing several of the key proposals previously made by the Tudeh. By that time the party's leadership was based in exile in East Germany, from where it actively commented on political developments in Iran and retained a keen interest in rural affairs.

The main features of agrarian relations between the 1940s and the 1960s have been the focus of a number of academic studies produced during the last few decades. Such works have either focused primarily on land tenure issues, delved into the sociology of the Iranian rural society of the time, or have assessed the reasons behind the state's increasingly assertive stance on the matter. The Tudeh attitude towards the issue, the patterns through which it sought to bring about peasant mobilisation and the aims of such activities are mentioned only in passing in the same works. ${ }^{2}$ The purpose of this article is therefore that of going beyond such accounts and providing a more systematic analysis of the Tudeh position and praxis on the peasant question between 1941 and 1953, the period in which the party was able to maintain a foothold on the Iranian public scene and engage directly with all strata of society, both before and after its formal banning in 1949.

\section{The Iranian Left and the Peasant Issue, 1906-1941}

Iran lacked the structured form of feudalism which had been prevalent in Europe in the preindustrial era. In contrast to their European peers, the Iranian peasants, who have been often referred to by through the term rai'yat, or serfs well into the twentieth century, were not bonded to the land they cultivated and maintained at least nominal freedom of movement. Another anomaly of the Iranian case consisted of the peculiarities of private land ownership which remained over the centuries, as noted by Cosroe Chaqueri, a privilege, rather than a legallyenshrined right. ${ }^{3}$ Large-scale private landownership depended to a large extent on the royal court's propensity to expand its holdings through confiscation and conquest, or reassign the same as a reward or as a pacifying gesture to its backers and functionaries. The start of the 
Qajar dynasty's rule at the end of the eighteenth century coincided with the increase in the amount of land under divani (or crown), or khalisah (state) ownership, both of which accrued to the royal court's possession by way of confiscation and the systematic revocation of the fragile claims on ownership present within Islamic canons. The time-honoured vaqf endowment system was at times embraced as a 'defence mechanism' against the 'encroachment of royal authority upon insecure, non-royal property'. ${ }^{4}$ Another form of land ownership, the tuyul, which mainly derived from the practice of providing land as a reward en lieu of financial outlays such as a military or civil salary, was formally abolished at the time of the constitution-writing process of 1906, but lands assigned through this mechanism remained in private hands following the upheaval of that period.

The agrarian question remained a vexing one by the start of the twentieth century due to the considerable diversity in the national climate, the relative paucity of fertile land in a country where over 60 per cent of the surface was desert and the general scarcity of water, which resulted in the success of cultivation depending upon either man-made irrigation systems or rainwater. The persistent weakness of the central state in the late nineteenth and early twentieth century and its inability or unwillingness to engage in a systematic initiative for the amelioration of the peasant condition meant that arable terrain across the country was effectively divided into a patchwork of fiefdoms where large landowners held sway.

By the early 1900s, land ownership in Iran could be broadly divided into five different categories. The absentee large and small-scale private landlords formed one group. A small segment of land was owned by middle and low-scale peasants who also lived and worked on the same. The crown and state lands (divani and khalisah), and vaqf formed three other groups. ${ }^{5}$ Several studies which have focused on the extent of ownership of each of these classes prior to the major state-driven land reform initiative of the 1960 s have converged on only 5-10 per cent of arable land being owned by petty landowners, with large landowners owning over half, tribal 
leaders holding around 15 per cent and state and vaqf lands amounting to around 10 per cent. $^{6}$ This breakdown is largely reflected in Ashraf's breakdown of land ownership related to the 1925-1960 period, which features a combination of the royal court, 100 large landowner families and tribal clans and several hundred other families as owning two thirds of arable land, while the vaqf and state lands and 750,000 small landowners each controlling less than a fifth of the total. ${ }^{7}$

The bulk of agricultural produce was the result of complex arrangements between sharecroppers, peasants and large landowners, who could therefore exploit their commanding position to extract surplus labour and other advantageous conditions from those who benefitted from nasaq, or cultivation rights. Such exploitation was mainly carried out through the mubashir class, a community of on-the-ground representatives of often urban-based landlords. ${ }^{8}$ The five-factor principle (land, water, cattle, seeds and peasant labour) was the main factor in the calculation of the landlord's share which, as shall be seen below, became a focal point of the post-1941 political scene's attention given to the agrarian question.

By the time the first wave of Iranian social-democratic movements had devised their initial programmatic statements and declarations in the period surrounding the Constitutional Revolution, the plight and turmoil of the peasant class featured high on the agenda of the radical manifestos which aspired to significantly alter the configuration of Iranian society. The formula proposed throughout the first decades of the twentieth century primarily consisted of rectifying the imbalance in ownership by calling for the transfer of land held by the royal court and large landowners. The Mashad programme of the Social Democratic League in September 1907 called for the confiscation of royal properties and that of largest landlords and the cost-free redistribution of the same amongst peasants. It also called for legally stipulated limitations on land ownership. Such views had gained traction even amongst elements of the liberal bourgeoisie. The Surisrafil periodical stated in several issues that peasants had the right to 
express opposition to current arrangements, defined the 'rai'yat ownership' as the basic principle for progress in agriculture in Iran and proposed the creation of a 'National Agricultural Bank' which would purchase land voluntarily handed over by 'patriotic princes, ministers and Khans' in depreciating instalments and sell shares in the same to landless peasants. $^{9}$ In similar vein, the resolution of the second congress of the Communist Party of Iran of 1921 called for the confiscation of both large and petty absentee landowners' possessions and their assignment to peasants, in order to combat the incomparable 'destitution and injustice' which had been hitherto practised against Iranian peasants. It also warned that peasant mobilisation needed to be flanked by 'urban revolutionaries' in order to upend the existing feudal order. ${ }^{10}$

The ability of such radical parties to influence state policy was curtailed by a number of factors. Riza Shah's authoritarian suppression of opposition activities and his predatory approach to the expansion of his terrains resulted in his rigid modernising agenda not affecting large-scale land ownership. ${ }^{11}$ The much-vaunted Civil Code reform of 1928 effectively strengthened the latter. Its attempted modernisation of land registration was in assistance to the landlords' ability to control and direct legal proceedings to their own advantage, in effect providing bureaucratic consolidation for the practice of large landowning, which had previously been subject to the ebbs and flows of the arbitrary style of governance of the Qajar monarchs. As noted by Nikki Keddie, the 'land registration laws were a step to modernisation accomplished at the expense of the peasants'. ${ }^{12}$ Furthermore, a series of laws geared towards selling off state land approved during the 1930s ostensibly for the purpose of augmenting the petty landowner class yielded the actual effect of increasing the amount of property under control of major landlords, particularly the cronies of Riza Shah. ${ }^{13}$ Their formal influence within village communities was further consolidated through a 1935 bill which made the kadkhuda appointable by landowners and liable for implementing government directives. ${ }^{14}$ 
The material conditions of the peasantry remained a visible element of societal backwardness. At the apex of the rule of Riza Shah, the seminal Marxist intellectual Taqi Erani delivered the following laconic assessment, which reflected the contemporary state's inability to bring about any form of progress in this regard:

The 6 million [out of the total national population of 10 million] peasants scattered across the Iranian national territory are usually financially poor and illiterate and locked into arcane beliefs and superstition. They cultivate land using very basic tools [...] Under the spell of these economic and social ailments, the Iranian peasant is generally cowardly, beholden to his masters and to primitive beliefs, cunning and deprived of the advantages of present-day civilisation.

Virtually no book is to be found in villages [...] the local cleric is the only literate member of the village community, and the press, including Dunya, do not have any sort of presence therein. ${ }^{15}$

Both Erani and the various socialist formations of the first decades of the twentieth century developed a holistic view of the Iranian peasantry and refrained from providing a more introspective analysis of the divergences in the condition of the peasantry across Iranian regions. This became apparent as the northern province of Gilan, which hosted the most fertile land of the country, became host to a long sequence of febrile initiatives by peasants between 1906 and 1921. As noted by Pezhmann Sadigh-Dailammi, 'the fertile land and abundant rainfall, the density of the peasant population, the absence of tribes' and the general prosperity of the region enabled the peasantry to function as a standalone class. ${ }^{16} \mathrm{~A}$ branch of the socialdemocratic movement mobilised the peasantry as early as 1907 in order to refuse to pay taxes to landowners. However, the Jangali movement, whose first military operations consisted of clashes against private, landowner-organised armed groups, fell short of presenting and 
implementing a comprehensive land reform programme. Once in control of urban centres in the wake of the Russian Revolution of 1917, the Jangalis proceeded to enforcing confiscation against landowners who were politically opposed to them. ${ }^{17}$

\section{The Tudeh Party of Iran and the Peasant Issue, 1941-1949}

The ban on all ishtiraki, or socialistic organisations enacted by Riza Shah in 1931 prevented the Communist Party and other leftist formations from organising an overt peasant wing. Such a limitation was largely overcome, however, following the fall from power of the first Pahlavi monarch in summer 1941. The Tudeh Party of Iran played a prominent overt role in the Iranian domestic political scene throughout the 1940s, and for brief periods succeeded in building a parliamentary and cabinet presence, through the three ministers it dispatched to Ahmad Qavam's national unity government in $1946 .{ }^{18}$ This phase came to an end through an attempt on the Shah's life in February 1949, which was swiftly blamed on the Tudeh and led to the formal banning of the party. Concerns over the attitude of the Soviet Union with regards to an uprooting of the party and the sequence of weak cabinets which took power in the immediate aftermath of this decision enabled the Tudeh to maintain a foothold in Iranian politics through the creation of front organisations such as the Jamiyat-i Milli Mubarizah ba Istimar (the National Society for Struggle against Colonialism), the Shura-yi Milli-yi Havadaran-i Sulh (The National Council of Peace Supporters, the Iranian branch of the global Peace Partisans movement) and, as shall be discussed below, the Anjuman-i Kumak bih Dihqanan, or Society for Aid to Peasants.

The Tudeh's early concern with the condition of Iranian peasants was a natural progression from debates and proposals which had been formulated by its predecessor formations. In the weeks following the abdication of Riza Shah, as a debate raged in the winter of 1941 over the return of lands confiscated by the monarch to their previous private owners, 
the Tudeh announced its opposition to the principle that the land was to be passed from 'usurper to usurper', as the two types of ownerships were essentially identical. The party proposed instead to assign the same at no cost to landless peasants. ${ }^{19}$

The early party organs frequently carried commentary which noted how the principles which hitherto governed agrarian relations were wholly to the detriment of peasants and petty landowners. It pressed for the introduction of mechanisation and for the reform of water rights and extraction mechanisms. ${ }^{20}$ Its early programmatic resolutions fell short, however, of echoing the radical stance of the Social Democrats or the Communist Party. During the first Tehran Provincial Conference, which marked in effect the inaugural gathering of the party, the prominent Central Committee member Iraj Iskandari, who was the Tudeh leader with the closest intellectual affinity to Erani, stated that the present-day condition of peasants was akin to that of the serfs of the Middle Ages, if not worse. He then noted the 'astonishingly luxurious lifestyle' of the absentee landowners, prior to noticing how European countries such as Britain, Germany, Romania and Czechoslovakia had to various degrees eliminated this archaic form of land ownership by purchasing the land and reassigning it to peasants. He then called for the abolition of large landownership through a process akin to the European one in terms of the purchase and redistribution of landowner-held terrains. The Iranian peasant had therefore to transition from bandah or servant, to malik-i kuchak, or 'smaller landholder'. ${ }^{21}$ In order to meet such a goal, the following points were included in the revised party programme which emerged from the Provincial Conference: 1) Large landowning should be completely eradicated, and such lands should be entirely purchased by the state; 2) Arable land should be redistributed and sold to peasants by way of long term instalment plans; 3) Khalisah lands should be immediately redistributed amongst peasants; 4) Agricultural banks should provide necessary capital for peasants to engage in making their agricultural and irrigation practices more efficient. ${ }^{22}$

This blueprint marked the first concrete attempt by a major political party of the post- 
Riza Shah era to introduce a scheme whereby private landowners would be dispossessed through compensation and peasants would be charged a fair instalment schedule for the same. The principle of the purchase of privately held land and its reselling to peasants at favourable rates held sway until the first party congress of August 1944. Besides reiterating all four points above, the new programme also called for 'fundamental reform' in the 'unjust' division of produce between landowner and peasant, introducing a system for the election of the kadkhuda, the landlord's representative within villages, and a concerted struggle against the malfeasance of government representatives in rural areas and the abolition of all arbitrary forms of taxation imposed by landowners. ${ }^{23}$ The extensive handbook produced by the party theoretician Ahmad Qasimi, who belonged to the more radical left-wing flank of the party, as a companion guide to the new programme lamented the fact that Iranian peasants were currently making use of tools which had remained fundamentally unaltered 'since the times of Cyrus and Darius the Great'. He also bemoaned their lack of ownership and control of water resources, which resulted in most peasants making sole use of rainwater for irrigation. The appearance of doctors in the midst of peasants was considered by rural inhabitants as being akin to a 'magical phenomenon'. Premature aging was noted as an endemic ailment of peasant society. The ongoing practice of bigari, a form of unremunerated labour which effectively featured as a kind of non-pecuniary taxation, was compared to forms of slavery. Qasimi did not, however, recommend the confiscation of land possessed by major landowners, and confirmed instead that the Tudeh accepted the principle of private ownership. ${ }^{24}$

The proposals made during the first congress for the improvement of the condition of peasants were implemented in September 1944 through the creation of a Peasants' Union, which consolidated the embryonic peasant associations which had emerged in the Sovietoccupied provinces of Northern Iran by $1943 .{ }^{25}$ The creation of the nationwide Union was made a necessity by the fact that at the time of the first congress only 2 per cent of party 
members hailed from the peasantry, while 75 per cent came from the modern working class, a statistic which reflected the advanced stage in the activities of the Central Council of Trade Unions, the body which organised industrial workers, particularly those active in the oil sector. ${ }^{26}$ The Union became a continuation and expansion of the activities of the fifth party committee in Tehran, which was dedicated to coordinating the early peasant-oriented efforts. ${ }^{27}$ The Union was coordinated through a central council which was under the purview of the Central Committee member Muhammad Bahrami. A group of university students and recent graduates, including Yusuf Gharib, Bagher Momeni, Sadiq Ansari and Hussein Nazari, who had mostly been active in the fifth committee formed the Organisation's leadership group. ${ }^{28}$

As noted by Sadiq Ansari, the Peasants' Union's activities faced both internal and external challenges. The lively urban setting of Iranian politics in the 1940s meant that most of the young university graduates and literate political activists who were drawn to the Tudeh preferred to discharge their party duties in Tehran or other major cities, and had therefore little or no willingness to relocate to the considerably more backwards and uninspiring countryside. The widespread illiteracy within peasant communities and their endemic distrust of inquisitive urban dwellers descending on their villages furthermore made the spread of party political literature and thought a challenging task. ${ }^{29}$ Nevertheless, the founding charter of the Union shows signs of the engagement that the Union was able to initiate with inhabitants of rural areas. The preamble contains a highly critical overview of contemporary peasant conditions and indirectly offers some context to Erani's aforementioned despairing remarks. It defines the latter as the class which provides the 'most beneficial contribution to society' and notes that the rai'yat span a spectrum between six and seventy years of age. It then focuses extensively on conditions in villages, noting how none of the basic amenities for healthy living, such as adequate foodstuffs, hygiene, medicine but also cultural and recreational activities are available in rural areas. The rai'yat's dwellings, the preamble continues, are often hovels situated within 
caves, and are to be considered inadequate even for animals. Nevertheless, entire peasant families lived there with their livestock, in an environment where fleas transmit diseases over to humans and the smoke of opium, which is decried as being cheaply provided by the state and the $a r b a b$ in order to weaken the spirit and physique of the rai'yat, mixes with the fumes deriving from the preparation of modest food and animal exhalations, thereby generating an 'unbreathable' environment. The inadequate nutritional value of the staple peasant diet resulted in shorter life expectancies, the rise of diseases such as malaria and typhus, a child mortality rate of 60 per cent and often only healthcare for one peasant every 50,000. ${ }^{30}$

Turning to aspects such as culture, amusement and recreation, the preamble noted how the illiteracy rate in 'civilised' countries stood at 2-3 per cent, while the figure was set at a staggering 99 per cent amongst Iran's peasant, urban worker and toiler population. The ra'iyat's persistent deprivation from the means to acquire knowledge or pursue an education was considered, in ways not entirely dissimilar to the previous considerations by Erani, to be part of the arbab's strategy previously pursued by Riza Shah of concealing and preventing better living standards and the spread of consciousness over full civil rights. ${ }^{31}$

After setting out the dire situation of the peasant community in the months immediately following the end of the Second World War, the Peasants Union's founding charter then proceeded to include the following elements amongst the key points of its initial aims: the purchase of large tracts of privately-owned land by the government, and the sale of those and khalisah ones to landless or smallholding peasants by way of an instalment payment system, whilst enacting legislation to prevent the re-emergence of large scale landowning; the creation of state-owned agricultural banks, with sufficient investment for assistance to peasants; the creation of peasant cooperatives to ensure the supply of essential goods at controlled prices, and state-owned companies for the exploitation of water resources for irrigation and electricity generation; the construction of better peasant housing stock, schools and sanitary units in each 
village. $^{32}$

In order to meet such objectives, the Unions' charter noted that a 'political' struggle, beyond the mainly 'economical' one of industrial workers such as those in the oil sector was necessary. Forms of mobilisation adopted in the latter setting, such as recurrent strike action, were considered impracticable in the rural case. Another key element was the need to ensure that peasants would acquire awareness on their general condition, a necessary condition for escaping from the arbab's stranglehold over their livelihood. This would prove to be a challenging proposition, due to the considerable variety in the arbab-rai'yat relationships across the country. Membership of the Union was open to landless peasants who were working on arbabi lands and on rented land. Petty landowners were also accorded membership upon condition of also working in their plots, or having 'common objectives' and working towards the good of deprived peasants. ${ }^{33}$

The Union volunteers who ventured to rural areas were to various degrees faced with the distrust and suspicion of peasants. With the exception of northern regions such as Gilan, Kurdistan and Azerbaijan, which had been briefly governed by radical, left-wing forces between 1919 and 1946, few of the other provinces had witnessed the kind of activities which were being promoted and enacted by the Union. ${ }^{34}$ The latter did, however, have a certain success in organising in scattered rural communities the country, at times in eclectic fashion. In the autumn of 1946, the peasants of Chardih, a village in Gilan, rallied in the local mosque against the mubashir appointed by Ahmad Qavam's Democratic Party and swore allegiance to the Tudeh Party on copies of the Quran. ${ }^{35}$ Another rally in Gilan in June 1946 called for the extension of healthcare and education to rural communities under a banner celebrating Erani. ${ }^{36}$

These localised initiatives did not achieve the broader intended breakthrough. As admitted retrospectively by the successor organisation to the Union, the latter's activities gained a measure of success in a limited number of regions, particularly in Gilan, Mazandaran, 
Isfahan, Malayir and the agricultural areas outside Tehran.

The Union never convened a nationwide congress which could bring supportive peasants from disparate areas together and instil esprit de corps in them. As sanguinely admitted by a prominent party sociologist a decade later, the continued concentration of party activity in the urban areas and its banning in early 1949 contributed significantly to stymying any significant Union expansion. ${ }^{37}$ Sadiq Ansari reaches similar conclusions but argues that the party's lack of necessary preparation for a vast scale, uniform mobilisation of the peasantry was also due to the extent of state-driven repression against the Tudeh in towns and smaller centres across the country during the 1940 s, which also resulted in the continued loss of party archival documents, particularly the reports of fieldwork conducted by the Union which affected the party's ability to formulate a coherent stance on the peasant question. ${ }^{38}$ Localised Union activities did, however, achieve some measure of success through unusual methods. Riza Tahiri, a Union organiser in the Garmsar region, recalled that the organisation took advantage of those parts of the Nahj al-Balaqih, the compilation of sayings and declarations attributed to the Shia Imam Ali, which were dedicated to social justice and the struggle against zulm, or oppression, which was associated with large landowners. Tahiri's branch also struck an efficient alliance with schoolteachers, held in high esteem within the peasant community, who assisted with reading out party literature to the largely illiterate peasant cohorts. ${ }^{39}$

The strategy undertaken by the authorities to contrast the rapid growth of the Tudeh influence amongst peasants consisted of replicating the Tudeh's organisational scheme. The Democratic Party of Ahmad Qavam, which was set up for the purpose of winning the fifteenth Majlis elections in 1945, swiftly built a network of supportive landowners and sought to mobilise peasants through rallies which were also attended by the mubashir, the kadkhuda and other similar figures who enforced landowner control in the village. ${ }^{40}$

As remarked in the resolution of the second Tudeh party congress, held in May 1948, 
the activities amongst peasants was decried as hitherto being 'mostly limited to superficial propaganda which was on occasion error-stricken'. These initiatives were further evaluated as lacking a well-defined organisational or proselytising element. ${ }^{41}$ The decision by the Qavam cabinet of 1945 to transfer 15 per cent of the share of the landowner to the peasant-producer was singled out, alongside the removal of archaic levies, as the signature elements deriving from the party activities in favour of peasants. However, Ansari notes that this slogan and other ones provided by the 'centre' often took precedence over more necessary local measures, such as agitating in favour of the creation of schools or sanatoriums. ${ }^{42}$

The incoming Central Committee was mandated once again to create a broad united peasant front, nationwide and local conferences, setting up special classes for training peasant cadres and creating a periodical devoted to rural issues. ${ }^{43}$ The new party programme confirmed the previous stance on the free redistribution of khalisah and other state lands and called once again for the purchase, rather than confiscation, of landowner-held terrain and its cost-less redistribution. $^{44}$

\section{The Society for Aid to Peasants, 1951-53}

The pledges made during the second congress were entrusted to a new unit devoted to rural issues within the roster of the front organisations which were formed following the banning of the party in February 1949. Following that date, the Tudeh effectively pursued the Leninist principle of combining overt and clandestine activity. The Society for Aid to Peasants (henceforth Society) continued to be staffed by white-collar urban young activists who maintained an interest in peasant matters. The Society's thirteen-strong governing council included four lawyers and jurists, including Murtaza Nahavandi, its head and Habibullah Davari, the editor of the Society's weekly periodical, Intiqad Barayi Dihqanan-i Iran (henceforth Intiqad). Nahavandi had been a contemporary of Grand Ayatullah Burujirdi in the 
seminary prior to parting ways with clerical life. He would be occasionally dispatched to Qum to mediate with Burujirdi at times of rising anti-party sentiment amongst the clergy, and would remind him that the wrath of the elite and the royal court against the Tudeh had the effect of blunting similar measures against the clergy. Burujirdi would wryly respond through an invocation for God to 'bless party members but prevent their success'. ${ }^{45}$ Alongside the aforementioned lawyers, Abdullah Yaghmai, a surgeon, Bagher Momeni, who would later become one of the twentieth century Iran's foremost historians, other former Union activists such as Gharib and Sadiq Ansari, two veterans of the Jangali movement in Gilan of 1915-20, Muhammad Ali Sharifi and Muzaffarzadah and one peasant, Nurullah Khamushi also formed its core leadership. ${ }^{46}$

As noted in the new formation's title, the Society declared in the months following the start of its activities that its primary duty was that of achieving improvements in the healthcare and cultural knowledge of peasants. In order to reach these objectives, the Society called upon healthcare professionals and teachers to provide their services pro bono to peasants. ${ }^{47}$ The Society also provided legal cover and assistance for those peasants involved in local disputes with particularly abusive landowners and to highlight the practices of the latter. The role of Nahavandi, Davari and the other legal experts was that of rushing to rural areas at times of unrest and providing urgent defence to imprisoned peasant activists. ${ }^{48}$ Gharib's memories include a particularly turbulent trip to the region outside Isfahan alongside Nahavandi, an urbane jurist ill-suited to the less refined aspects of rural reception and hospitality. The expedition resulted, however, in the dropping of charges against several peasants and their release from the detention imposed by a local sergeant who would later become the secret police Savak's first chief, Taymur Bakhtiar. ${ }^{49}$

The publication of Intiqad, the period's only journal entirely devoted to peasant matters, matched the commitment made at the second party congress and enabled the Society to develop 
bonds with inhabitants of rural areas. A network of literate supporters would read out the contents of every issue to the mass of peasants who were unable to do so. ${ }^{50}$ Gharib, who retained a penchant for satire throughout his life, became the lead writer of a column called Amu Haidar (Uncle Haidar), which was occasionally augmented through content from Chilingar, the seminal and thought-provoking Tudeh-oriented satirical publication almost entirely written in verse.

The Society's broad network of representatives also ensured a steady stream of news regarding local developments, which were printed regularly in Intiqad. The 'News from Iranian Villages' section regularly carried peasant-submitted reports on injustices they faced, such as the mubashir of a village in Savchibulaq in the Alborz province refusing to supply water for irrigation, or readers from Varamin informing the publication that the landowner General Shafa engaged in his latest outrage by instructing notoriously corrupt local gendarmes to douse the houses of peasants with petrol. ${ }^{51}$ It insisted from the start that the widespread lack of land ownership by peasants was the root cause of their malaise and deprivation while warning that peasants could only improve their situation through a united effort with urban workers, which it defined as the only class who would engage in a fruitful alliance with the peasants themselves. ${ }^{52}$

In contrast to its predecessor Union, the Society organised frequent local meetings and convened a national general assembly on 13 December 1951, marking the first nationwide peasant congress in modern Iranian history. During the four-day event, which was held at the party's youth wing headquarters in Tehran, representatives from virtually every agricultural region of the country took to the podium. Their views were aptly summed up by the delegate from the southern Fars province, who remarked that it was the first time ever that 'a group of jointly-suffering peers' were congregating from far-flung corners of the country in order to exchange views on their joint predicament. ${ }^{53}$ Similarly to other speakers, he did not point to 
tangible, long-term results already achieved by the Society, thereby suggesting that the latter had not yet overcome the Union's limitation in securing short-term, local improvements to the condition of peasants. Speaking on a broader issue, the representative for Gilan noted that the new elections bill proposed by the Musaddiq government ruled out enfranchising illiterates once again, which meant that 99 per cent of peasants could be deprived of the right to vote. ${ }^{54}$

The Society also sought to narrow the urban-peasant divide by frequently organising events in party facilities in the cities, and organising karavan-i sulh, or 'Peace Caravans', which would feature young industrial workers and students heading to rural areas for bonding with peasants and raising their awareness on the campaigns promoted at the time by the international Peace Partisans movement. The Society eventually dispatched a peasant to the Congress of the People for Peace of Vienna of December 1952. ${ }^{55}$

\section{The Tudeh Party and Other Land Reform Initiatives, 1945-51}

Alongside the fervent peasant-oriented activities of the Tudeh seen above, the transformation of land ownership became a pressing concern in the post-Constitutional Revolution period. As noted above, a string of bills was approved during the 1920s in order to raise the productivity of khalisah lands and relieve the state from ownership of parts of them. Such tentative attempts at reducing the amount of arable land under state control were, however, decisively undermined by Riza Shah's systematic land predation, which possibly turned him into the Middle East's largest landowner by the end of the 1930s.

From the start of the reign of his son and successor Muhammad Riza, the principle of the redistribution of the now considerable crown and khalisah lands to peasant ownership gained traction within various strands of the political elite. The new monarch showed little propensity to maintain ownership over the vast properties bequeathed to him by his father. On

21 September 1941, Muhammad Riza turned all such properties to the government, which in 
turn upheld crown ownership over a series of recreational Pahlavi estates in northern Iran. ${ }^{56}$ This development enabled many of the landowners who had been previously dispossessed by Riza Shah to seek the return of their property. On 2 June 1942, the parliament approved a law which enabled these landowners to advance claims on any land which was taken over by the first Pahlavi monarch, a move which was seen as an implicit admission of the unjust nature of Riza Shah's initiative. ${ }^{57}$ During the drafting of the bill, the initial Tudeh newspaper Mardum raised the concern that "no one appears to be caring about the shameful conditions in which nine tenths of the inhabitants of this nation, the peasants' or to be proposing any process for improving their condition. ${ }^{58}$ The scheme was in particular embraced by Hasan Arsanjani, a mercurial journalist and politician who became the main non-Tudeh proponent of radical approaches to land reform between the 1940s and 1960s. ${ }^{59}$ From the first stages of the postRiza Shah era, Arsanjani wrote frequently about the need to weaken or remove the grip of large landowners over arable land. As opposed to many prominent political figures of the time, Arsanjani's parliamentary career never took off, as his confirmation was rejected through a concerted effort by Nasir Zulfaqari, the notoriously despotic landowner of the Zanjan region, in early September 1947. Zulfaqari explained his opposition by noting Arsanjani's election from the Lahijan constituency, the stronghold of his political patron Ahmad Qavam in which he had no interests, and his active calls for mending the lacunae of the constitution, which cast doubts over his loyalty to the Mashrutah state order. These were effectively ruses designed to conceal the efforts by Zulfaqari - who had been prominently singled out as an acute example of a feudal landowner during the Pishavari administration - and his peers to eject their main opponent from the new fifteenth legislature. ${ }^{60}$ In 1949, probably influenced by the continuous Tudeh agitation within peasant communities, Arsanjani submitted a detailed plan to the prime minister of the time, Haj-Ali Razmara, for the sale of khalisah lands to newly formed peasant co-operatives. ${ }^{61}$ Arsanjani sought in this way to exploit signs of an apparent yearning for broad 
social reform by the Shah. In early 1951 , he reacted to a Majlis address on the topic by the monarch by attacking through his Dariya periodical the slow pace of land reform, and portraying, as he would do in the following decade, the redistribution of wealth as an essential step towards ensuring a greater loyalty of the people towards the state. He then called upon the Shah to take matters into his own hands by giving away the considerable amount of land he had inherited from his father. ${ }^{62}$ For the next couple of months, Dariya became the beacon of radical solutions for land reform, for example proposing a jihad against landowners on grounds that the 'enslavement' of peasants would continue while the former's control over land was undiminished. ${ }^{63}$

These persuasive calls eventually resulted in the first implementation of redistribution of lands under the possession of the Shah at Varamin on 16 March 1951, through which approximately a thousand peasants received ownership. This initiative marked the first of a series of modest land redistributions of crown lands. The initiative was met with little reaction by either the National Front, the umbrella group of supporters of Muhammad Musaddiq, or the Tudeh, most likely due to its overlap with the approval of the oil nationalisation bill then under way in Parliament. Nevertheless, Varamin remained an important focus for Society activities between 1951-53, and featured the candidacy of Yaghmai, who was local to the region, in the Seventeenth Majlis elections. ${ }^{64}$

The Varamin redistribution marked the second concerted initiative at land reform in the post Riza Shah era. The first was undertaken by the Firqah-i Dimukrat administration during the year in which it governed the northern, agriculture-rich Azerbaijan region under Soviet protection. A particularly rigid form of landowner domination over peasants had been the norm in the region for centuries. ${ }^{65}$ On 16 February 1946, the Azerbaijan National Assembly approved a bill for the redistribution of 810 villages, or 380,000 hectares of khalisah and privately-owned terrains under Firqah control. ${ }^{66}$ According to article 1 of this bill, the 
possessions of large-scale landowners, who were considered to be owning up to 80 per cent of arable land in the region, were to be confiscated if they had either fled or were agitating against Firqah rule. ${ }^{67}$ Article 2 stipulated the creation of a joint commission composed of representatives from various ministries, including justice, interior, finance, commerce and agriculture. A mechanism for appealing confiscations within a month was also included. According to articles 11 and 12, the arbab had to resolve their differences with the peasants. A new agricultural bank was also set up to provide financial assistance for mechanisation and other improvements to agricultural techniques. ${ }^{68}$

The approval of the land bill underpinned the convening of the first peasant congress of twentieth-century Iran. The gathering took place at the Firdawsi hall in Tabriz on 14 April 1946, with the presence of over 600 delegates. Three days prior to this seminal event, the Firqah administration released an addendum to the February law which stipulated that the yearly produce was to be divided at 50 per cent between remaining landowners and peasants, who would therefore get a share far higher than the peers in the rest of the country. ${ }^{69}$ Addresses to the congress reiterated how agriculture was at the heart of the administration's economy. The aforementioned land confiscation bill was expanded upon, alongside an indictment of the previous rulers' arbitrary redistribution practices. The orator cited in particular the case of a Qajar-era masseur who was granted a gift in land from the Shah as appreciation for his kisah massages. ${ }^{70}$ The Pahlavi era practices were lambasted for having engaged in the sale of state land at very cheap prices to select aristocrats. ${ }^{71}$

Referring to the current land distribution efforts, the congress noted that the Agriculture Ministry first sought to dispatch its own bureaucrat to oversee the redistribution processes, but the lack of time and resources compelled them instead to send a representative for each village, who would collaborate with a rish safid, or respected elderly chosen by the villagers themselves, who would in turn bring about a five-member commission which would proceed 
to implementing the redistribution. The congress also pledged to build sanatoriums and schools.

Despite not being an active part of this land reform initiative, the Tudeh would later often extol the Azerbaijan process as a seminal moment in peasant emancipation following the collapse of the Firqah administration in $1946 .^{72}$

\section{The Tudeh Party and Musaddiq's Agricultural Bills of 1952-53}

The Musaddiq government which was formed in the weeks following the Varamin redistribution did not devolve significant attention to the peasant issue prior to the 30 Tir (July 1952) incident. Following his return to power on the cusp of the brief popular uprising, Musaddiq proceeded to announce a nine-point reform plan, which was to be implemented through the special powers he requested and obtained to rule without legislative approval for a period of six months. The first major initiative which was announced during this phase was the 'Bill for the Augmentation of the Farmers' Share and the Agricultural Construction Organisation', which was introduced on 13 August 1952. A separate, briefer bill introduced simultaneously forbade landowners from receiving livestock, foodstuffs and unremunerated labour as taxation from peasants.

According to the Augmentation Bill, the 15 per cent reduction in the share of the produce assigned to landowners, previously decided by the Qavam administration, was now raised to 20 per cent, half of which was to be paid over directly to the peasant, and the other half to be allocated to improvements in village infrastructure, particularly the provision of clean water, and public buildings such as mosques, communal baths, and storage. This bill also stipulated the creation of cheap housing, schools and medical centres, increasing rural sanitation awareness and education, and preventing plant and livestock epidemics. All inhabitants of a village, including landowning peasants and those not working on the land, or khushnishin, were 
mandated to devolve 3 per cent of their earnings to a cooperative fund which would be used for the aforementioned infrastructural purposes and which was also to be funded through lowinterest loans provided by the Agricultural Bank.

In order to coordinate these various activities, the bill stipulated the creation of a threelayered council structure. The lowest level of the latter was formed by a Village Council composed of five members, as follows: a representative of the landowner, the local kadkhuda, and three respected locals chosen by the peasants. All Council members had to be at least 20 years of age, have a clean judicial slate and meet a literacy requirement, which restricted the ability of peasants to choose an illiterate member for more than the time it took to seek a literate replacement. The next step up featured two entities which received 50 per cent of the infrastructural budget: the dihistan, or council formed of a set of villages which decided on major funding or infrastructural projects through the participation of the local governor and representatives from Village Councils and landowners, and finally the regional, or bakhsh council which incorporated the previous bodies across a greater surface area. ${ }^{73}$

The August 1952 bills marked an earnest attempt in seeking to improve the condition of peasants and rural infrastructure while sidestepping the vexing issue of land ownership. Rather than focusing on the primary concern of the Tudeh, the government sought to instil duties within the existing landowner-peasant relationship in order to bring about quality of life improvements and an increase in productivity based on the increase in peasant profit and welfare. Such a focus was probably due to the continued heightened presence of landowners in state institutions, most particularly the Majlis. ${ }^{74}$ According to statistics compiled by Shajii, 59 per cent of the members of the seventeenth legislature belonged to the malik class, despite the annulment of the elections themselves in around half, mostly rural constituencies, due to likely tampering by landlords. ${ }^{75}$ 
The publication of the bills was conducive to a spirited debate within the political scene. The main pro-government daily championed their contents by noting how the same were 'without precedent' in Iranian history, due to the hitherto primordial conditions of the peasantry and remarked how both foreign and domestic observers still chose to compare the same to medieval serfs. It then noted how the continuation of the current situation would effectively mark a form of 'collective public suicide' for a nation which was sharing $2000 \mathrm{~km}$ of border with a 'major communist country' such as the Soviet Union. The persistence of the kind of unfair conduct brought about hitherto by the large landowners, the editorial continued, had the potential of generating the most robust case for the expansion of communism in Iran. ${ }^{76}$ The same analysis admitted, however, that the bills introduced by Musaddiq could only be considered as a first step towards a more complete reform, which had to include the principle of tahdid, or legal limitation of large land ownership, and called for the purchase of arable terrain from the $a r b a b$ and its sale to peasants by instalment. The editorial concluded that both the practice of agriculture and the condition of the peasantry would be severely inhibited until the landless peasants will become owners. ${ }^{77}$ The Zahmatkishan Party, which was at that time strongly supportive of the government and strenuously opposed to the Tudeh, also had a mixed reaction to the bills and stated that Musaddiq 'could have, and should have taken more profound steps for the reform of agriculture'. It also noted the vagueness of the shorter bill, which ostensibly had the aim of banning arbitrary landlord-imposed levies, actually paved the way for additional taxation due to its vague and unclear structure. ${ }^{78}$ As remarked within a British Embassy report prepared shortly after the publication of the bills, the Zahmatkishan's lukewarm reaction was probably due to its leader Muzaffar Baqai's failed effort to push through a parliamentary bill of his own to increase the peasants' share by 15 per cent, which was higher than the 10 per cent share accruing to the peasants through Musaddiq's bill. ${ }^{79}$

Establishment sources voiced moderate support for Musaddiq's initiative. An editorial 
in the Kayhan daily confirmed, for example, the view that the majority of Iran's population was of peasant stock, but the present condition of the latter was a major collective cause of concern. It noted, however, that the contents of the two bills 'help in improving the conditions of agriculture, but do not constitute a permanent cure for the ailments' noted previously. It pinpointed the root cause of such a situation as being the persistence of the arbab-ra'iyat relationship, and passionately argued that 'the real landowner is the person who works the land in the cold and the heat' ${ }^{80}$

The content and line carried forward in these editorials highlights the fact that even some elements of the political class of the time had endorsed a position which bore considerable similarity, if not full overlap, with the proposals put forward by the Tudeh during the 1940s, particularly the resolution of the first congress and the founding charter of the Peasants' Union. By the time Musaddiq's bills were published, however, the Tudeh had moved beyond its previous appeasement on the right to compensation of large landowners and had converged instead on a radical version of the Second Congress resolution. In the days following the publication of the bills, the various party organs collectively called once again for the expropriation of large landowners and the redistribution of their land for free to peasants. The Society noted in particular that Musaddiq, whom it termed a 'large landowner' by virtue of his possession of several villages in the Savchilagh area, had decided to tend to his own interests by promoting bills which 'do not meet any of the fundamental demands of the peasants, ie. water and land possession, but on the other hand had reduced even the previous 15 per cent [of the share of the landlord which had been reassigned by the Ahmad Qavam administration in August 1946]'. The same analysis also charged the prime minister with reviving several levies which had been discontinued in all but a few select villages. ${ }^{81}$ It also urged peasants to exploit an apparent ambiguity in the bill on whether the stipulated 20 per cent was in addition to the 15 per cent re-assigned by Qavam by pressing large landowners to honour both payments. 
Landless peasants were furthermore urged to persuade petty landowners of the proposition that paying the 15 per cent share was to their advantage and created unity against the common 'feudal' enemy. ${ }^{82}$ Despite an initial overtly negative reaction, the Society urged its members and supporters to take part in village council elections, with a view to ensuring that landowner representatives would have a minor role in the same. The Central Committee's own reflections on the bills noted that the same had the intention of forming a 'kulak' class within Iranian rural communities and stated that no reform taking place under the aegis of the current 'feudal' arrangement of land ownership would be beneficial to peasants. It then highlighted the bills' shortcomings in this regard to press for the unity between landless peasants, those less destitute and petty landowners against the feudal and large landowners. ${ }^{83}$

A few months later, in early June 1953, the Musaddiq government passed another bill which placed crown lands previously seized by Riza Shah and now relinquished by his son Muhammad Riza to government control. It stipulated that a new Khalisah Institution was entrusted with administering the land and diverting profits to the charitable Shahinshah Foundation and in preparation for other socially worthy initiatives, such as a new Agricultural Faculty. ${ }^{84}$ The Society criticised the government decision by noting the prime minister's reluctance to grant ownership to peasants, as article 4 of the bill called for the 'sale and assignment of khalisah land according to laws and regulations previously approved by Majlis', which the Society considered to be an effective return to the Riza Shah-era facilitation of the expansion of large landowners' possessions, as the latter were the only actors who could benefit from such provisions ${ }^{85}$

Musaddiq's bills had therefore the effect of drawing the Tudeh and the National Frontled government further apart on the peasant issue. An internal critical retrospective assessment of the relationship between the Tudeh and the National Front noted several years later that even though the dispossession of arbab properties and the free redistribution of the same to landless 
peasants was an essential condition for the resolution of the land issue, the Musaddiq bills were a 'step forward' with regards to the status quo and in order to acquire added welfare for peasants. The same were not to be considered 'reactionary', as implied by the contemporary Tudeh analysis, but were rather progressive due to the conditions of the peasant communities, which had not yet reached the required level of awareness for large-scale struggle and mobilisation, and concluded by criticising the Tudeh's uncompromising opposition to Musaddiq's proposals. ${ }^{86}$

\section{The Kurdish Exception}

Despite its robust criticism of the Musaddiq bills, the Tudeh did not lend its support to the peasant rebellion in the Kurdish region of Mukriyan which emerged in the weeks following their publication. As noted by Vali, the rebellion's origins rested in the particularly harsh conditions hitherto imposed on Kurdish sharecroppers, and were fomented by the peasants' conviction that the Musaddiq administration had finally resorted to enacting legislation which would assist their quest to limit the landowners' ability to enact arbitrary forms of taxation and levies. ${ }^{87}$ Initial support for the bill morphed, however, into demands originally made by a Bukan tailor called Haj Ghasim, for landowners to surrender the full documentation related to land sales which had been completed financially but not legally. The ensuing widespread rebellion was eventually put down through joint efforts by the landowners and the army. ${ }^{88}$

Despite the similarity between the demands of at least part of the Kurdish peasantry and the various Tudeh critiques of the Musaddiq bills, there was little sign of concern or support for the Mukriyan rebellion within party organs at the time. This can be at least partly explained by the Society's lack of presence in Kurdish rural areas, which is made apparent by the lack of a representative from that region in the aforementioned annual assembly and by the sparse news from Kurdistan published in Intiqad's otherwise exhaustive reports on peasant mobilisation in 
other regions. The Tudeh's inability or unwillingness to engage substantially with the Kurdish issue may also have been due to special circumstances which were governing that region's agrarian relations. In contrast to the Azeri case, the Mahabad Republic administration was unable to propose or implement any substantial land reform plan. As explained by Qasimlu, prior to the establishment of the Kurdistan Democratic Party (KDP), 78 per cent of the region's arable land was controlled by large, mostly tribal landowners or Aghas, with peasants being in control of 8 per cent. ${ }^{89}$ The fifth article of the founding statement of the KDP contained the pledge to find an understanding between the $a r b a b$ and the ra 'iyat and assure the prospects of both through a 'general law'. ${ }^{90}$ Such development did not, however, take place during the Mahabad Republic era. As noted by Hawar Nerwiy, the Aghas strong hold on the livelihoods of peasants prompted Qazi Muhammad, the leader of the KDP, to avoid confrontation with the Aghas and therefore refrain from engaging in an initiative comparable to the one undertaken by Jafar Pishihvari in Tabriz. ${ }^{91}$ The KDP's reaction to the Musaddiq bills contained an analysis of the pattern through which the state would purchase all the tobacco and beet crop from the Kurdish peasants. The government was pressed to raise the price of the purchased crops amid the KDP echoing the Tudeh's depiction of the establishment as a whole being beholden to the landowners. $^{92}$

The Tudeh Party's apparent lack of interest in the Kurdish issue was also probably due to its minimal presence in the region. As recalled by Ghani Bulurian and Qasimlu, the Tudeh dispatched half a dozen lower ranking members to Kurdistan in 1951 at the request of the KDP in order to provide a political education for the latter's fledgling cadres. ${ }^{93}$ At the time of the Mukriyan rebellion, the Tudeh had a skeleton presence in the area, one which was mostly devoted to ideological training and was bereft of the ability to significantly affect the Mukriyan rebellion, which marked the only sustained case of peasant unrest in Iran during the Musaddiq years. 


\section{Conclusion - An Impassioned but Inconclusive Attempt at Peasant Mobilisation}

Between its foundation in 1941 and the coup against Musaddiq in 1953, the Tudeh Party of Iran devoted significant attention to the plight and conditions of the Iranian peasantry. The topic featured extensively in the deliberations of the main party conferences and two bodies were created with the specific aim of mobilising the peasantry and seeking to bring about a lasting bond between the latter and urban workers. The circumstances of the time also enabled the party to make deeper inroads than its predecessor organisations in the Iranian Left, whose ability to go beyond proclamations and resolutions in favour of the peasantry was stymied by their lack of presence within rural communities.

From the outset, the Tudeh identified the vagaries and shortcomings of the Iranian land ownership structure as the main element upon which the campaign for the improvement in the conditions of the peasantry should be structured. It had, however, to contend with a challenging environment, which included a very low initial party membership deriving from the peasant component of society, the persistence of landowner abuses of power, and ultimately a party leadership and organisation which failed to attribute the same resources devoted to urban and industrial worker mobilisation towards the peasant question, thereby confirming the prevalently urban nature of the Tudeh itself.

The August 1953 coup against Musaddiq resulted in the suppression of all Tudehaffiliated organisations and prevented any breakthrough in the Society's activities and halted the possibility of extra-governmental initiatives for land reform. As noted sanguinely at the end of the 1950s in the internal party analysis, the role and participation of the peasantry and tribal folk in the oil nationalisation movement and national political developments between 1951-53 remained limited, thereby constituting a major weakness of the nationalisation movement due to the 'near totality' of the army rank and file being of peasant or tribal extraction. ${ }^{94}$ These 
factors also reduced the possibility of peasant uprisings forestalling the machinations against the Musaddiq government or reverting its overthrowal.

Despite the Tudeh's lack of success in achieving the broader political mobilisation of the peasantry, a circumstance it shared with virtually all its peers, the party's sustained activities in the rural realm between 1941 and 1953 yielded several important results. The Society for Aid to Peasants succeeded in building a network of sympathetic rural supporters, which in turn enabled the Society's journal, Intiqad to maintain a valuable ongoing voice and record of peasant demands. From 1941 onwards, the party and its associated organs insistently shifted the attention on the systemic iniquity of land ownership patterns which held sway in Iran as late as the middle of the twentieth century, which in turn resulted in a remarkably high degree of similarity in the reaction of the Tudeh and its main pro-government foes to the Musaddiq bills of August 1952. The Tudeh's lack of a foothold within the state sphere and its continuously inimical relationship with the rest of the scene, including the National Front and Musaddiq, prevented further collaboration between the Society and progressive elements of the executive and legislative branches who shared sympathy on the destitute nature of the Iranian peasantry and led the Party as a whole to adopt a resolutely negative attitude to the prime minister's agrarian-related bills of summer 1952, which marked an earnest attempt to redress the imbalance in landowner rights and privileges without pivoting on the thorny question of land ownership.

Following the coup of August 1953, the Tudeh lost the ability to maintain a cogent and direct presence in rural areas and resorted to becoming an interested bystander as the state progressively came around to the idea of engaging in sustained land reform. Several of Tudeh veterans, such as Gharib, ended up however serving in the Agriculture Ministry from the end of the 1950s, and were a likely influence in the formulation of the land reform plan included in the Pahlavi state's White Revolution. 


\section{Acknowledgements}

The Author would like to thank Nasser Mohajer for his careful comments on earlier drafts of this article, Banafsheh Massoudi for providing essential primary sources, Parisa Toloue Hayat Azar and Marouf Cabi for their kind assistance with documents in the Azeri and Kurdish languages and Touraj Atabaki, Leonard Michael and the staff at the Archiv für Forschung und Dokumentation Iran (Berlin) and the International Institute of Social History (Amsterdam) for their help in locating other Persian language material.

This article is dedicated to Bagher Momeni (1926-), a former founder and prominent member of the Society for Aid to Peasants who for the past several decades has been a seminal historian of Iran and pioneering public intellectual.

\section{Notes}

1 Fakhreddin Azimi, Iran: The Crisis of Democracy 1941-1953 (London: I.B. Tauris, 1989), p.1.

2 See Ali M. Ansari, Modern Iran Since 1797 (London: Routledge, 2019), Abbas Amanat, Iran: A Modern History (New Haven: Yale University Press, 2017), and Homa Katouzian, The Persians (London and New Haven: 2010) for examples of recent survey works which have focused primarily on the state's ambitions. Specialist monographs such as Mohammad Javad Amid, Poverty, Agriculture and Reform in Iran (London: Routledge, 1990), Ann K.S. Lambton, The Persian Land Reform, 1962-66 (Oxford: Clarendon Press, 1969), Eric J. Hooglund, Land and Revolution in Iran, 1960-1980 (Austin: University of Texas Press, 1982) or Afsaneh Najmabadi, Land Reform and Social Change in Iran (Salt Lake City: University of Utah Press, 1987) provide a wealth of data and explanation on the implementation of land reform by the Pahlavi state but do not discuss the Tudeh's attitude in any depth. The topic is broached in Asghar Schirazi, Islamic Development Policy: The Agrarian Question in Iran (Boulder: Lynne Rienner Publishers, 1993), but this work mentions only in passing the continuous contributions which the Tudeh produced mostly through the Dunya periodical in the 1960s. Other studies which provide extended accounts of the history of the Tudeh, such as Sepehr Zabih, The Communist Movement in Iran (Los Angeles: University of California Press, 1966) and Maziar Behrooz, Rebels with a Cause: The Failure of the Left in Iran (London: I.B. Tauris, 2000) are similarly bereft of a systematic appraisal of the Tudeh's peasant policy. On the other hand, Bagher Mumini, Masalah-i Arzi va Jang-i Tabaqati dar Iran [The Land Question and Class War in Iran] (Tehran: Payvand, 1980) contains a valuable partial scrutiny of the attitude of the Tudeh and other elements of the Iranian Left towards the earlier phases of statedirected land reform, while Shams Mamedovich Badii, Munasibat-i Arzi dar Iran [Land Relations in Iran] (Tehran: Intisharat-i Akhgar, 1980) covers several episodes of Tudeh-induced peasant mobilisation during the 1940 s and 1950s.

3 Cosroe Chaqueri, The Russo-Caucasian Origins of the Iranian Left: Social Democracy in Modern Iran (Richmond: Curzon, 2001), pp.46-47.

4 Chaqueri, The Russo-Caucasian Origins of the Iranian Left: Social Democracy in Modern Iran, p.47. 5 This breakdown is derived from Farhad Kazemi and Ervand Abrahamian, 'The Nonrevolutionary Peasantry of Modern Iran', Iranian Studies 11, no. 1/4 (1978), pp.267-68 and Mumini, Arzi, p.28. 
6 See Kazemi and Abrahamian, 'Nonrevolutionary', p.270 for a sample of such studies. These figures are derived from Muhammad Sawdagar, Nizam-i Arbab-Rai'yati dar Iran [Landowner-Serf Relations in Iran] (Tehran: Muassisah-i Tahqiqat-i Iqtisadi va Ijtimayi-i Pazand, 1980), p.124, and represent patterns of land ownership immediately prior to the land reforms of the 1960s. They therefore include the trickle of khalisah lands which had been assigned to landless peasants after 1941.

7 Ahmad Ashraf, State and Agrarian Relations Before and After the Iranian Revolution, 1960-1990 in Peasants and Politics in the Modern Middle East (Miami: Florida International University Press, 1991), p.284.

8 Ibid., pp.284-85.

9 Overview of Surisrafil content on land ownership in Mumini, Arzi, pp.87-88.

10 Congress Resolution in Khusraw Shakiri (ed.), Asnad-i Tarikhi-yi Junbish-i Kargari, Susyal Dimukrasi va

Kumunisti-i Iran [Historical Documents of the Worker, Social Democratic and Communist Movement of Iran] Vol.1 (Paris: Intisharat-i Padzahr, 1990), p.50.

11 According to Ashraf's aforementioned survey, Riza Shah acquired as many as 5600 agricultural estates during his reign.

12 Nikki Keddie, Stratification, Social Control and Capitalism in Iranian Villages: Before and After Land Reform in Rural politics and social change in the Middle East (Bloomington: Indiana University Press, 1972), p.372.

13 Mumini, Arzi, p.96.

14 Ali Shakoori, The State and Rural Development in Post-Revolutionary Iran (London: Palgrave Macmillan, 2001), p.49.

15 Dunya, No.6, Tir 1313 [June-July 1934], pp.1-2.

16 Pezhmann Sadigh-Dailami, 'Nationalism and Communism in Iran: The Case of Gilan, 1915-1921', (PhD

Thesis, University of Manchester, 1994), p.15.

17 Sadigh-Dailami, 'Nationalism', pp.70-71.

18 It is outside the scope of this article to provide a detailed account of Tudeh activities between 1941 and 1953. The two most comprehensive overviews of the same are to be found in Ervand Abrahamian, Iran Between Two Revolutions (Princeton: Princeton University Press, 1982) and Jami, Guzashtah, Chiragh-i Rah-i Ayandah Ast: Tarikh-i Iran dar Fasilah-i Du Kudita [The Past, A Guiding Light for the Future: A History of Iran between the Two Coups] (Paris: Jibhah-yi Azadi-yi Mardum-i Iran, 1976).

19 The Tudeh's early stance on the fate of Riza Shah's lands in Mumini, Arzi, p.103.

20 'The Role of Economic Reforms', Siyasat, 21 Khordad 1321 [11 June 1942].

21 Iskandari's speech to the first Tehran Provincial Conference, Namah-i Rahbar, 14 Bahman 1321 [3 February 1943].

22 'Land belongs to Peasants', Namah-i Rahbar, 13 Bahman 1321 [2 February 1943].

23 Programme as approved by the first party congress in Namah-i Rahbar, 16 Shahrivar 1323 [7 September 1944].

24 Ahmad Qasimi, 'Hizb-i Tudah Chih Miguyad va Chih Mikhvahad' [What does the Tudeh Party Want and Say?] in Asnad-i Tarikhi-yi Junbish-i Kargari, Susyal Dimukrasi va Kumunisti-i Iran, Vol.1 (Florence: Mazdak, 1974), pp.218-35. During the 1970s, the party cadre in charge of agrarian affairs, Amir Nik-Ayin, would explain that the prevailing political situation, particularly the ongoing Second World War, compelled the Tudeh to choose a path of 'moderation' when facing traditional adversaries.

25 According to Iskandari the first peasant mobilisation efforts began in the northern Mazandaran province in 1943 and spread to southern provinces outside the Soviet sphere such as Fars, Isfahan and Kirman by the end of that year. Iraj Iskandari, 'Histoire du Parti Tudeh' Part III, Moyen-Orient 7, January 1950, as republished in Cosroe Chaqueri (ed.), Un Prince Iranien Rouge En France: Vie et Oeuvres du Communiste Iradj Eskandari (Paris: Mazdak, 2002), p.166.

26 A further 23 per cent of party members were either intellectuals or white-collar workers. Abdulsamad Kambakhsh, Nazari Bih Junbish-i Kargari va Kumunisti dar Iran [Reflections on the Worker and Communist Movement of Iran] Vol.1, (Stassfurt: Intisharat-i Hizb-i Tudah-yi Iran, 1972), p.69.

27 Yusuf Gharib, Hizb va Tanz [Party and Satire] (Tehran: Parchin, 2016), p.31.

28 Sadiq Ansari, Az Zindagi-yi Man: Pa Bih Pa-yi Hizb-i Tudah-i Iran, [From My Life: Step by Step with the Tudeh Party of Iran] (Los Angeles: Nashr-i Kitab, 1996), pp.120-21. Ansari, a crucial element of early party efforts at mobilising the peasantry, frequently laments in his memoirs the scale of the persuasion efforts required to attract more attention to his remit during rural-themed gatherings at the party's central headquarters in the mid-1940s.

29 Ansari notes for example how many peasants initially had no understanding of 'party' or 'union', and were of the belief instead that the central government had finally decided to dispatch its representatives to rural areas after years of neglect. Ansari, Zindagi, p.106. 
30 These points are contained in the preamble of the Peasants' Union charter, as published in Namah-i Rahbar, 2 Tir 1324 [23 June 1945].

31 Ibid.

32 Extracted from ibid.

33 Sadiq Ansari, Chihil va Panj Saal Paykar-i Khastigi Napazir dar Rah-i Sazmandihi va Rahai Dihqanan-i Iran [45 Years of Relentless Struggle for the Organisation and the Emancipation of the Iranian Peasants] (Intisharat-i Hizb-i Tudah-yi Iran, 1987), p.33.

34 According to Badii, the focal points of peasant activism throughout the 1940s consisted of the provinces of Tehran, Isfahan, Kirman, and the regions of Gilan (particularly around the agricultural centres of Fuman and Lashtnisha), and pockets of Khuzistan. Badii, Munasibat, p.121.

35 Namah-i Rahbar, 19 Aban 1325 [10 November 1946].

36 Badii, Munasibat, p.119.

37 Parviz Khalatbari, 'Hizb-i Tudah va Junbish-i Dihqanan dar Salha-yi 1320 ta 1332' [The Tudeh Party and the Peasant Movement of the years 1320 to 1332 (1941 to 1953)], Dunya 4 (1962).

38 Ansari, Paykar, pp.54-55. Tahiri also notes that the 15 per cent re-allocation remained mostly on paper in many rural areas, due to the landowners' power to refuse to implement the same.

39 Hamid Ahmadi (ed.), Guzar Az Kuha-yi Sarhur: Khatirat-i Riza Tahiri [Crossing the Sarhur Mountains: Memoirs of Riza Tahiri] (Berlin: Anjuman-i Mutaliat va Tahqiqat-i Tarikh-i Shifahi-yi Iran dar Birlan, 2006), p.72.

40 See in this regard the reminiscences of a peasant from Garmsar supportive of the Tudeh in Intiqad, 12 Tir 1330 [4 July 1951] who was coerced by his landowner to take part in one such Democratic Party rally in Tehran.

41 Resolution of the Second Party Congress in Masayil-i Hizbi, No.1, Tir 1327 [June 1948], p.97.

42 Ansari, Paykar, pp.56-57.

43 Masayil-i Hizbi, No.1, p.98.

44 Ibid., p.99.

45 Gharib, Hizb, p.34.

46 Ansari, Zindagi, p.249 and Gharib's notes on the Society in Gharib, Hizb, p.33. Neither of these two memoirs provide an exact date for the start of the Society's activities. Intiqad was published from early 1951 until August 1953.

47 Intiqad, 22 Khurdad 1330 [13 June 1951].

48 Ansari, Paykar, p.68.

49 Gharib's reminiscences in Bahman Zibardast (ed.), Bih Dunbal-i Sarab [In Search of a Mirage] (Tehran: Shirkat-i Sahami-yi Intishar, 2017), p.91.

50 Tahiri recalls for example, that the aforementioned joint endeavours with school teachers in the Garmsar region ensured that issues of Intiqad, which would be received regularly via train transport from Tehran, would be read out to peasants. Ahmadi, Guzar, p.72.

51 Both instances as reported in Intiqad, 12 Tir 1330 [4 July 1951].

52 Overview of Society aims and activities in Intiqad, undated special issue marking the Society's first anniversary.

53 Report on proceedings in Intiqad, 27 Azar 1330 [18 December 1951].

54 Ibid. The bill was eventually published in December 1952 and stipulated that each of the exclusively male voters had to write and cast the ballot himself. This was an implicit rejection of the right to vote of illiterate peasants, whose inability to engage in the voting independently was often exploited by landowners to their own advantage. The Tudeh accused Musaddiq in this instance of disenfranchising peasants through, for example, placing landowners and allied officials in control over electoral supervisory councils. Discussions of the electoral bill in Mardum, 3 Dey 1331 [24 December 1952] and Bisuy Ayandah, 28 Azar 1331 [19 December 1952].

55 Report of Muhammad Karim's trip and speech in Intiqad, 17 Dey 1331 [7 January 1953]. This occasion marked the first time an Iranian peasant featured as a speaker in a major international conference held in Europe.

56 Mustafa Nuri, Ruzigar-i Biqarari [The Period of Uncertainty] (Tehran: Saziman-i Asnad va Kitabkhanah-i Milli-yi Jumhuri-yi Islami-yi Iran, 2015), p.81.

57 Ibid., p.84.

58 Mardum, 18 Bahman 1320 [7 February 1942] as cited in ibid., p.85.

59 See Abbas Milani, Hassan Arsanjani in Eminent Persians (Syracuse: Syracuse University Press, 2008) for an insightful biographical note on Arsanjani and the more extended study produced by his brother, Nuraldin Arsanjani, Duktur Arsanjani dar Ayinah-i Zaman [Dr Arsanjani in the Mirror of the Times] (Tehran: Nashr-i 
Qatrih, 2000). Arsanjani's land reform policies will be examined in more detail in a forthcoming study which will focus on the Tudeh Party and the peasant question in the 1960s.

60 Mustafa Alamuti, Iran dar Asr-i Pahlavi, (London: Book Press, 1988), p.268.

61 Lambton, Land Reform, p.50.

62 Lambton, Land Reform, p.51.

63 Dariya article described in Lambton, Land Reform, p.53.

64 According to Sadiq Ansari, the lively campaign for Yaghmai featured considered peasant participation, but was ultimately disrupted and quelled in a heavy-handed manner by police intervention. An elite figure, the Kayhan editor Abdulrahman Faramarzi, eventually took the seat.

65 See Najleh Khandagh, 'Political Parties in Iran 1941-1947: With Special Reference to Firqa-yi Dimukrat in Azerbaijan', (PhD Thesis, University of Edinburgh, 1984), p.239 for examples of despotic practices by landowners over peasants.

66 Statistics from Touraj Atabaki, Azerbaijan: Ethnicity and the Struggle for Power in Iran (London:

I.B.Tauris, 2000), pp.149-50.

67 In this regard, the bill mimicked the aforementioned Jangali decision to engage in confiscation against its political enemies within the landowning class.

68 Text of the bill in Azarbaijan, 5 Isfand 1324 [24 February 1946]. This discussion of the bill is also informed by Khandagh, 'Political Parties', pp.239-46.

69 As noted in Badii, Munasibat, p.119, the local Peasants' Union in Rafsanjan, close to Kirman, succeeded, on the cusp of developments in Azerbaijan, in striking a deal for the reduction of the landowner's share of the produce from 75 to 50 per cent by mid-June.

70 Reported in Azarbaijan, 16 April 1946.

71 Ibid.

72 See for example the positive appraisal of the free redistribution of khalisah land during the Firqah administration in Mardum, 19 Azar 1331 [10 December 1952]. The Firqah initiative retained a positive legacy within the Azarbaijan region, as observed by Hooglund in his fieldwork there two decades later. Hooglund, Reform, p.160.

73 Text of the bills in Bakhtar-i Imruz, 23 and 24 Murdad 1331 [14 and 15 August 1952].

74 As noted more critically by Vali, 'The conservative ethos of the bill was indicative not only of the political orientation of its authors, but also of their recognition of the political power and influence of the landowning class in the civil and military apparatuses of the state.' Abbas Vali, The Forgotten Years of Kurdish Nationalism in Iran (Cham: Palgrave Macmillan, 2020), p.57.

75 Zahra Shajii, Namayandigan-i Majlis-i Shawra-yi Milli dar Bist va Yik Dawra-yi Qanunguzari [The

Representatives of the National Assembly in 21 Legislatures] (Tehran: Intisharat-i Muassisah-yi Mutaliat va Tahqiqat-i Ijtimai, 1965), p.177. This mark a gradual rise from previous legislatures, which featured a figure slightly in excess of 50 per cent.

76 Bakhtar-i Imruz editorial, 23 Murdad 1331 [14 August 1952].

77 Ibid.

78 Shahid, 23 and 24 Murdad 1331 [14 and 15 August 1952].

79 British Embassy Tehran, Confidential Report No.265, 25 August 1952, in FO 248/1531 Internal Political Situation Iran, 1952.

80 'A First Step towards Reform', Kayhan, 25 Mordad 1331 [16 August 1952].

81 'Regarding the Law for the Augmentation of the Farmers' Share', Qiyam-i Dihqan (replacing Intiqad), 29 Murdad 1331 [20 August 1952]. The Zahmatkishan Party had also made a similar remark regarding the reemergence of previous levies.

82 Qiyam-i Dihqan, 6 Shahrivar 1331 [27 August 1952]. Further calls were made here for 'assemblies' to bring together a common platform between peasants and petty landowners.

83 Mardum, 1 Shahrivar 1331 [23 August 1952].

84 Text of the bill in Ittilaat, 16 Khurdad 1332 [6 June 1953].

85 Intiqad, 20 Khurdad 1332 [10 June 1953]. It was noted here that landowner control over Parliament would prevent any relaxation of such measures to the benefit of landless peasants.

86 Rawshan, 'Munasibat-i Hizb Tudah-i Iran va Jibhah-yi Milli dar Salha-yi 1328-1332' [Relations between the Tudeh Party of Iran and the National Front between 1328 and 1332 (1949 and 1953)] Masayil-i Hizbi 7 (1958), p.20.

87 Vali, Nationalism, pp.55-60.

88 Ghani Bulurian, Aleh Kuk: Khatirat-i Ghani Bulurian [Green Leaf: Memoirs of Ghani Bulurian] (Tehran: Muassisah-i Khadamat-i Farhangi-yi Rasa, 2005), pp.146-47.

89 Abdulrahman Qasimlu, Chihil Saal Mubarizah dar Rah-i Azadi [40 Years of Struggle in the Path towards 
Freedom] (Suleimaniyah: Ittihadiyah-i Danishjuyan-i Dimukrat-i Kurdistan-i Iran, 2012), p.24.

90 KDP founding statement, reproduced in Refiq Salih and Sediq Salih (eds), Rojname-i Kurdistan: Mehibad 1324-1325 [Kurdistan Newspaper, Mahabad, 1324-1325 (1945-1946)] (Suleimaniyah: Binke-i Jin, 2007), p.300.

91 Hawar Khalil Taher Nerwiy, 'The Republic of Kurdistan, 1946', (PhD Thesis, Leiden University, 2012), pp.159-60.

$92 \mathrm{KDP}$ analysis of the Mussadiq bills in Kurdistan, No.141, 10 September 1952. This series was published in Baku as an insert in each issue of Azarbaijan, which retained its role as the central organ of the Firqah in exile after the collapse of the Pishihvari administration in 1946.

93 Bulurian, Kuk, pp.137-40, Qasimlu, Mubarizah, p.254. Qasimlu, who later became the leader of the KDP, was the point of contact between the latter and the Tudeh.

94 Rawshan, 'Munasibat', p.15. 